\title{
Socio-economic Factors Influencing Migration: The Case of Eastern Zone Tigrai Regional State, Ethiopia
}

\author{
Getahun Belete Worku \\ Department of Economics, College of Business and Economics, Jinka University, Jinka, Ethiopia
}

\section{Email address:}

getahunbelete2127@gmail.com

\begin{abstract}
To cite this article:
Getahun Belete Worku. Socio-economic Factors Influencing Migration: The Case of Eastern Zone Tigrai Regional State, Ethiopia. International Journal of Science, Technology and Society. Vol. 9, No. 2, 2021, pp. 62-74. doi: 10.11648/j.ijsts.20211002.14
\end{abstract}

Received: January 26, 2021; Accepted: March 10, 2021; Published: March 17, 2021

\begin{abstract}
Background: Migration is the movement of people from one place to another place. This type of movement can be permanent, temporary, volunteer or forced. People can move from one place to another place outside its country, like moving from Asia to Europe, like moving from Ethiopia to America and inside its country, like adigrat to Addis Ababa and from Gondar to Humera immigration. People migrate from place to place due to different reason among these economic, social, political and environmental reason are take a lion share. Materials and Methods: The main goal of this study was to investigate the causes migration from eastern zone of Tigrai. The study focuses on to identify the socio economic and demographic factors of migrant to leave their place of origin in the study area. To achieve this objective, both quantitative and qualitative methods were employed. The Primary data was collected mainly from the returnee migrants, zone Labor and Social affairs office and from any sample of the study area economically active adult populations (15-49). The data gathered from four purposefully selected (discrete) in eastern zone. The tools used to gather the primary data were questionnaires. A total 180 respondents were selected for survey questionnaire by using simple random sampling technique from purposefully selected discrete. Descriptive statistical method was employed to analyze these quantitative data by using stata software and also Binary Logistic regression was also applied to analyze the determinant factors of migration by using stata software. Results: The result of the study indicated that migration is dominated by young aged (15-25), single male or female, their education level are primary education, their job unpaid family worker and those their family size are large. unemployment, poverty, agricultural land scarcity, individual wants to open up personal business, natural disaster like famine drought, low access to credit and experience of crop failure are the key push factors of migration. On the other hand, employment opportunities, better income from abroad and smugglers at destination country are identified as pull factors of migration. The main determinant forces or variables significantly affect migration decision in econometric analysis were age, family size, family shocks, family or individual respondent land size and high income at destination. Regarding the way of migration most of migrants were out illegal way about $75 \%$ Based on these findings.
\end{abstract}

Keyword: Migration, Illegal Migration, Binary Logit Model, Returnee Migrant, Non Migrant

\section{Introduction}

Migration is the movement of people from one place to another place. This type of movement can be permanent, temporary, volunteer or forced. People can move from one place to another place outside its country, like moving from Asia to Europe, like moving from Ethiopia to America and inside its country, like adigrat to Addis Ababa and from Gondar to Humera immigration. Permanent migration is when someone moves from one to another and has no plan to return his/her original home. Temporary migration is limited by time. This could be for seasonal employment. Forced migration involves the migration having no choice while voluntary migration is done by self-need without force [10].

Migration usually takes place at a variety of scale; intercontinental (between continents), between countries of a given continent, and interregional (with in countries) [12]. According to International Committee for Migration Policy Development cited in Bisrat [5] Population mobility in and from the Horn of Africa has a longstanding tradition. However, conflict, environmental deterioration and economic decline paired with growing economically active populations 
have increased labor and forced migration both in the region and beyond.

People migrate from place to place for different reasons. As it is expressed by the International Organization for Migration cited in Abrha [1], the main reasons for migration of people from one place to another place are: economic, social, political and environmental. As this organization justified it, the economical migration is related with moving to another place to find work or peruse a particular career. Social migration is to be closer for families or friends for a better quality of life while political migration is moving to another place to escape war or political persuasion and environmental migration occurs as a result of nature disasters like earth quake (IOM), cited in Belayneh et al [1].

The pattern of international migration continues from less developed to the industrialized countries, while flows are also taking place between developing countries. It is a multifacetted and complex global issue which today involves every country in the world [2]. In spite of its complexity, the factors of migration decision are generally grouped into "push" or "pull" factors. The "pull" and "push" factors of migration can be economic or non-economic. Push factors are associated with the conditions in the place of origin of migrants and seem to be more important in the developing world whereas pull factors are factors which attract people at the destination countries like job opportunities, political stability, better life and the like [8].

Massey \& others further asserts that at micro level individuals are the actors decide to migrate because of a cost benefit calculation lead to them to expect a positive net return usually monetary from movement. The central concept in the microeconomics theory of migration, according to different scholars, is 'Human Capital'. People are motivated to move from country to country because they thought that doing so will reward their 'human capital' and will have a future monetary return [11].

African migration is fundamentally a family affairs rather than an individual activity." Sending of remittances by migrants is identified as one of the strongest and most allencompassing phenomena in Africa's migration systems. [3].

In Ethiopia, international migration began mainly as a result of the political turmoil following the 1974 popular revolution. The young and educated Ethiopians migrated to the West because of the political instability of the country at the beginning. Later, however, the economic issues became the main motive of Ethiopian migrants. Even though, international migration has a short history it is in rapid spread throughout the country. Within the Horn of Africa, for instance, Ethiopia is the major source country for labor migration to Saudi Arabia until the ban on labor migration to the Gulf States by the government between 100,000 and 200,000 Ethiopian migrants migrated to Saudi Arabia annually through regular labor migration for the last three consecutive years, irregular Ethiopian labor migration to Saudi Arabia is estimated to be double that size [9].

Potential Ethiopian migrants choose irregular means of migration since this option is perceived to be less bureaucratic and time consuming, cheaper and more rewarding. According to UNHCR more than 512,000 Ethiopian migrant between 2006 and March 2016 through Djibouti or Punt land cross into Yemen, mostly aiming to transit through Yemen towards Saudi Arabia and other Gulf states along the shores of Red Sea, Gulf of Aden and Arabian Sea. Emigrant got different types of human right abuse during the time of migrating and from their destination like sexual harassment and unfair treatment, In addition it seems easy to emigrants to drop their identity and adopt the host countries ways of life as they are relatively less educated and helpless to be against ill-practices that they did not experience in their home country [15].

The Government of Ethiopia has adopted a series of development policy and program frameworks, particularly since the beginning of the millennium until nowadays, then there are a lot of works that people can work in the country; there is a relatively good access of education and scientific way of agricultural production but The problem of migration is a raising issue in the country at this time specially to middle east countries. So why do people made migration is not well known and number of studies that assess migration has been conducted in Ethiopia but most of them are concerned with internal migration and less is done on international migration, in addition to this, since there have been almost no research conducted so far in this area. This initiated to conduct a research in the eastern zone of Tigrai. Therefore this study attempts to fill the knowledge gap by employing binary logit model to investigate socio-economic factors influencing migration in eastern zone of Tigrai.

\section{Material and Method}

The study focuses on the socio economic factors influencing migration: the case of eastern zone of Tigrai. In order to address the stated objectives and research questions of the study, this chapter is structured as follows: the first section explains about description of the study area, the second section elaborate about the research design, the third section represents about sampling design, the fourth section of this chapter is about research data collection tools and instrument and the final section is about method of data analysis and model specification.

Research design

In order to achieve the objectives of this study and thereby to give answer for its problems mixed research approach were used in this research that means both quantitative and qualitative research designs. There are compelling reasons why the researcher chooses to use mixed methods. This quantitative method is supplemented by a qualitative method to complement/validate information gathered from the quantitative survey, to gain deeper insights on the issue, to significantly strengthen the analyses and thus enhance confidence in the conclusions.

Study Location: this was Eastern zone of Tigrai regional state which found in the most northerly part of the Ethiopia bordered by afar regional state in the east, by South Eastern 
zone in the south, by Central zone in the west and by Eritrea in the north.

Study Duration: September 2020 to January 2021.

Sample size: 202 individuals

Samples and Sampling Procedures

The target populations of this study were economically active age group (15-49) individual these are non-migrant, and returnee migrant from abroad in the study area, According to Belayneh and Sagar [4] this age group are the most economically active and migratory age group. Hence, the sampling technique which the researcher was employs multi stage purposive sampling technique to select sites and draw sampled individual adult for the study. Then four wordas with higher outmigration are purposefully select from nine administrative units in eastern zone of Tigrai. These are Irob woreda, Gilomehda woreda, Atsbi wenberta woreda and Adigrat town. Among these Woredas, four kebeles were selected purposefully; that means one from each Woreda these kebeles are Dewuhan from (Irob woreda), 04 from (Adigrat town) administration, Fatsi from (Gilomehda) and Felege woyni from (Atsbi wenberta) woreda. The kebeles were selected by their accessibility based on the information gets from zone and woredas officer. Finally research participants were selected from a total 20135 young adults individuals aged (15-49) in four kebeles by using simple random sampling technique.

Sample Size Determination

To determine a representative sample size from the target population, different strategies can be used according to the necessity of the research work. For this study researcher employ Following yemane, the sample size determination formula:

$$
\mathrm{n}=\frac{N}{1+N\left(e^{2}\right)}
$$

Where, $\mathrm{n}$ is the sample size, $\mathrm{N}$ is the population size and $\mathrm{e}$ is the level of precision. Let this formula be used to determined sample size, in which $\mathrm{N}=20135$ with 7\% precision. Assuming 93\% confidence level and e $=0.07$, we get the sample size as

$$
\mathrm{n}=\frac{20135}{1+20135\left(0.07^{2}\right)}=202
$$

Then primarily the study was employed 202 individuals which were distributed randomly to each individual adult respondent based on economic sector engage in the study area. However, Out of 202 questionnaires, 180 questionnaires were filled and found useful for the study. From total of 180 individuals 64 were migrants and the other 116 were nonmigrant respondents.

Data sources and Methods of Collection

Based on the research problem and objectives, both primary and secondary data sources were use. Primary data were collect by using administering a structured questionnaire to concerning selected age group of (15-49) in eastern zone Tigrai.

Method of data analysis
The method of data analysis was carried out in this study comprises both descriptive and econometric analysis. After the completion of data collection, the data were analyzed, edited, coded, classified and tabulated the demographic and socio-economic variable quantitatively and qualitatively using descriptive analysis including frequency, mean and standard deviation, t-test for the continuous and chi-square for the discrete independent, percentage computations, graph and tables. Regression analysis is another tool that has been used in the second part of analysis. To this effect binary logistic regression which signifies the effect of each independent variable on the dependent variable has been employed.

\section{Specification of Econometric Model}

Logistic regression assumes meaningful coding of the variables, Logistic coefficients were difficult to interpret if not coded meaningfully, the convention for binomial logistic regression is to code the dependent class of interest as 1 and the other class as 0 , the dependent variable must be categorical and it must be Absence of multicollinearity. Logistic regression does not assume a linear relationship between the dependent and independent variables, the dependent variables do not need to be normally distributed, there is no homogeneity of variance assumption, in other words, the variances do not have to be the same Within categories, normally distributed error terms are not assumed [14].

Following the logistic probability function for outmigration is defined as.

$$
p_{i}=\operatorname{prob}\left(Y_{i}=1 / X_{I}\right)=1-\frac{e^{-x_{i \beta}}}{1+e^{-x_{i} \beta}}=\frac{e^{x_{i \beta}}}{1+e^{x_{i \beta}}}
$$

As shown above, if $P i$ is the individual probability to be involved in out-migration and the probability of individuals not to be involved in migration, that is, $1-P i$, is given as follows.

$$
1-P_{i}=\operatorname{prob}\left(Y_{i=0 / X_{i}}\right)=\frac{e^{x_{i \beta}}}{1+e^{x_{i \beta}}}=\frac{1}{1+e^{x_{i \beta}}}
$$

The odds ratio is the ratio of the probability that individual would be participate on migration (Pi) to the probability that individual would be non-participate of migration (1-Pi). The odds ratio is given by:

$$
\frac{p_{i}}{1-P_{i}}=\frac{\operatorname{prob}\left(Y_{i}=1 / X_{I}\right)}{\operatorname{prob}\left(Y_{i=0 / X_{i}}\right)}=\frac{\frac{e^{x_{i \beta}}}{1+e^{x_{i \beta}}}}{\frac{1}{1+e^{x_{i \beta}}}}=e^{x i \beta}=e^{\beta 1 \mathrm{X} 1+\beta 2 \mathrm{X} 2 \ldots+\beta \mathrm{kXk}}
$$

The natural logarism of the odds ratio (logs-odds ratio) is therefore:

$$
\begin{aligned}
\ln \left(\frac{p i}{1-p i}\right)= & \beta X=\beta 0+\beta 1 \text { g e } n \text { d e } r+\beta 2 \text { age }+\beta 3 \text { Fsize }+\beta 4 \text { FLsiz } \\
& +\beta 5 \text { Iabroad }+\beta 6 \text { Fshocks }+\beta 7 \text { edulevel }+ \text { ei }
\end{aligned}
$$

Where, $\beta 0$ is intercept term

ei is error term

$\beta 1, \beta 2, \beta 3 \ldots . . \beta 9$ are coefficients of variables [8].

Therefore, individual migration decision is the function of 
factors that this study want observe are gender, age, family size, income earned from abroad, total family rural farm size, family shocks and education level of individual respondents.

Variable definition and hypothesis

Different variables were expected to have an effect on individual to out migrate in the study area. However, the major variables expected to have influence on the individual to out migrate are explained below. Before that it is better to explain the dependent variable

The dependent variable of this study is migration decision of adults from eastern zone of Tigrai. For the purpose of this study, the response variable migration is indicated by returnee migrants and non-migrants. Therefore, the outcome of migration decision is represented by $\mathrm{Y}$ with two possible values coded as 1 and 0 .

\section{$\mathrm{Y}=\left(\begin{array}{c}1 \text { if the respondent is migrants } \\ 0 \text { if the respondent is non migrants }\end{array}\right)$}

There are about seven explanatory variables three are discrete and four are continuous that were expected to influence individual migration decision. Abbreviations, description, and characteristics of explanatory variables of model are illustrated in the following (table 1 below).

Table 1. Abbreviations, description, and characteristics of explanatory variables of the model.

\begin{tabular}{|c|c|c|c|c|c|c|}
\hline $\mathbf{S} \mathbf{N}$ & Variables & Abbreviations & $\begin{array}{l}\text { Characteristics } \\
\text { of variables }\end{array}$ & $\begin{array}{l}\text { Expected } \\
\text { influence }\end{array}$ & Variable Description & Value \\
\hline 1 & $\begin{array}{l}\text { gender of the } \\
\text { individual } \\
\text { migrants }\end{array}$ & Gender & Dummy & Positive & $\begin{array}{l}\text { Sex is one of basic demographic factors that determine } \\
\text { migration related to structure and growth of population. } \\
\text { Adult men and women hold different motivations for } \\
\text { migration. Female migrants with high cultural influence, } \\
\text { social responsibility, and economic constraint motivate } \\
\text { towards the migration decision compared to men. }\end{array}$ & $\begin{array}{l}(1=\text { female } \\
0=\text { male })\end{array}$ \\
\hline 2 & $\begin{array}{l}\text { Education } \\
\text { level of } \\
\text { individual }\end{array}$ & Edulevel & Dummy & Positive & $\begin{array}{l}\text { The level of education in individual is also a potentially } \\
\text { important determinant of migration decision Individual } \\
\text { completed secondary school are highly motivate toward } \\
\text { migration decision compared to illiterate }\end{array}$ & $\begin{array}{l}1=\text { literate, } \\
0=\text { illiterate }\end{array}$ \\
\hline 3 & $\begin{array}{l}\text { Income } \\
\text { earned in } \\
\text { destination }\end{array}$ & Iabroad & Continuous & Positive & $\begin{array}{l}\text { The income earned in out of country as compared to income } \\
\text { in their origin is the major motivator migration. }\end{array}$ & \\
\hline 4 & $\begin{array}{l}\text { Total rural } \\
\text { farm size of } \\
\text { individual or } \\
\text { their family }\end{array}$ & FLsize & Continuous & $\begin{array}{l}\text { Negativel } \\
\mathrm{y}\end{array}$ & $\begin{array}{l}\text { Amount of land received from parents reduces the } \\
\text { likelihood of sons' migration because it indicates the earning } \\
\text { potential in the rural area. Sons and daughters from poorer } \\
\text { and landless households and from villages with less } \\
\text { agricultural potential and size are more likely to migrate }\end{array}$ & \\
\hline 5 & $\begin{array}{l}\text { Family } \\
\text { shocks }\end{array}$ & Fshocks & Dummy & Positive & $\begin{array}{l}\text { Family shocks for example death, divorce, family disputes } \\
\text { also affect migration decision. }\end{array}$ & $\begin{array}{l}1, \text { presence } \\
\text { of shocks } 0 \text {, } \\
\text { absence of } \\
\text { shocks }\end{array}$ \\
\hline 6 & Family size & Fsize & Continuous & Positive & $\begin{array}{l}\text { It is hypothesized that larger sized households have higher } \\
\text { number of individual migrating internationally }\end{array}$ & \\
\hline 7 & Age & Age & Continuous & $\begin{array}{l}+/- \\
\text { (indiffere } \\
\text { nce) }\end{array}$ & & \\
\hline
\end{tabular}

\section{Results and Discussions}

The measurements and findings of the factors that affect individual out migrate in the study area have covered both descriptive and econometric analysis by using STATA software. The descriptive analyses are used tools such as mean, t-test, chi-square and percentage of all independent variables which are expected influence on individual to out migrate. Econometric analysis was used to estimate the logistic regression model for the most important determinants of migration decision among the individual in eastern zone of Tigray region.

Descriptive analysis

Out of 180 individual considered in the analysis aged (1549), 64 were individual returnee emigrant remains 116 non migrant. In other word 35.5 percent of adult population participate migration and the remaining 64.5 percents of adult population were not involving migration at the time of data collection from Gender composition of respondents: Gender is one of basic demographic factors perhaps the most important form of social differentiation that influence migration propensities, Adult men and women hold different motivations for migration. Female adult with high cultural influence, social responsibility, and economic constraint motivate towards the migration decision compared to men. As this study show that migration propensities is dominated by female with percentage of $(59.38 \%)$ and (40.63) for males from the return migrants. However, for non-migrants, the figure is almost the same, about (44.82\%) were males and $(55.17 \%)$ were females and the chi-square test indicated that there is significant systematic relation between migration participation and individual sex category at less than $10 \%$ of significant level $(\mathrm{p}<0.1)$ (see table 2 below). 
Table 2. Migrtion participation and sex category of individual.

\begin{tabular}{|c|c|c|c|c|c|c|c|}
\hline \multirow{3}{*}{ Sex } & \multicolumn{4}{|c|}{ Migration participation } & \multirow{2}{*}{\multicolumn{2}{|c|}{ Total $(\mathrm{N}=180)$}} & \multirow{3}{*}{$\chi^{2}$} \\
\hline & \multicolumn{2}{|c|}{ Migrants $(N=64)$} & \multicolumn{2}{|c|}{ Non migrants $(\mathrm{N}=116)$} & & & \\
\hline & Count & $\%$ & Count & $\%$ & Count & $\%$ & \\
\hline female & 38 & 59.38 & 64 & 55.17 & 102 & 56.66 & \\
\hline Male & 26 & 40.63 & 52 & 44.82 & 78 & 43.33 & 3.4914 \\
\hline Total & 64 & 100 & 116 & 100 & 180 & 100 & \\
\hline
\end{tabular}

Computed From Own Survey, 2021 Age of individual respondent

The age of majority migrants are very young at the time of their first Migration, The proportion of migrants remarkably decreased with increasing in age. Several migration studies have revealed that the majority age level is concentrated in young adult age groups, even though the occurrence of migration can be seen at all age levels. In supporting this idea, the result of the this study shows that the rate of migration is found significantly highest for those belonging to the age category of (15-25) followed by (26-35), and (3649 years) about $(75 \%),(23.43 \%)$, and $(1.56 \%)$ respectively for return migrants. However, it is different for non-migrants, about $(47.41 \%)$ are categorized under (26-35), followed by (42.24\%) under (36-49), and (10.34\%) under (15-25). The mean of age individual participating on migration and these who are not participating were 23.48 and 35.43 respectively and the overall mean of age sample individual was found to be 31.18. Standard deviation of age individual participating on migration and these who are not participating were 5.45 and 7.72 respectively and the mean difference of the age were 11.94 and it is also significant at less than $1 \%$ level of significance. From this analysis, one can understand that the most migratory age groups from the return migrants are the productive forces (15-25). According to the National Youth Policy of Ethiopia (2004), the youth categorized "between" the age groups of 15-29 are the productive force. This age group nearly the same with dominant migratory age group in this study (see table 3. below).

Table 3. Percentage Distribution of Respondents by age.

\begin{tabular}{|c|c|c|c|c|c|c|c|}
\hline \multirow{2}{*}{ Variable } & \multirow{2}{*}{ Categories } & \multicolumn{2}{|c|}{ Migrant $(N=64)$} & \multicolumn{2}{|c|}{ Non migrant $(\mathrm{N}=116)$} & \multicolumn{2}{|c|}{ Total $(\mathrm{N}=\mathbf{1 8 0})$} \\
\hline & & Count & $\%$ & Count & $\%$ & Count & $\%$ \\
\hline \multirow{4}{*}{ Age of individual respondent } & $15-25$ & 48 & 75 & 12 & 10.34 & 60 & 33.33 \\
\hline & $26-35$ & 15 & 23.43 & 55 & 47.41 & 70 & 38.88 \\
\hline & $36-49$ & 1 & 1.56 & 49 & 42.24 & 50 & 27.77 \\
\hline & Total & 64 & 100 & 116 & 100 & 180 & 100 \\
\hline Mean & & 23.48 & & 35.43 & & 31.18 & \\
\hline SD & & 5.45 & & 7.62 & & 8.98 & \\
\hline MD & 11.94 & & & & & & \\
\hline $\mathrm{p}$-value & 0.000 & & & & & & \\
\hline
\end{tabular}

Source: Own Survey, 2021

Educational level of Respondents: Education level is one of the basic factors of adult migration. As indicated in the data from respondents of this study also shows that the propensity to migrate is decreases in the preparatory, $10 / 12+$ special training and higher educational attainment due to adult give more concerned directly to learning rather than migration decision issues. Although the findings of CSA [6]. in Ethiopia showed that $70 \%$ of the migrants were illiterate, according to the result of this study, illiterates were the lowest of all education status. In the present study, results show that From the return migrants, about $(18.75 \%)$ were illiterate, (51.56\%) were Primary School (1-8), 15.63\%, were Secondary/ preparatory school (9-12), $10.93 \%$ were $10 / 12+$ special training and College/University graduate were about $3.13 \%$. On the other hand, from the non-migrants, the illiterate were about $(5.17 \%)$, primary $(12.07 \%)$, secondary
(9-12) (19.83\%), 10/12+special training (39.6\%) and college/university graduate (23.28\%). the result of this study also shows that most educated one are categorized under non-migrants, About $39.66 \%$ were $10 / 12+$ special training followed by $(23.28 \%)$ college/university graduate and $(19.83 \%), \quad(12.07 \%), \quad(5.17 \%), \quad$ were represent secondary/preparatory school (9-12), primary (1-8) and illiterates respectively. According to the result of the study, the highest proportion of migrants is seen on the primary education level and illiterates. About (51.56\%) from the return migrants were categorized in the primary education level and about $18.75 \%$ were also illiterates. Based on this result, one can understand that the most exposed groups for migration were the primary education level and illiterates (see table 4 below). 
Table 4. Distribution of sample individual respondent by education level.

\begin{tabular}{|c|c|c|c|c|c|c|c|}
\hline \multirow{2}{*}{ Variable } & \multirow{2}{*}{ Categories } & \multicolumn{2}{|c|}{ Migrants } & \multicolumn{2}{|c|}{ Non migrants } & \multicolumn{2}{|l|}{ Total } \\
\hline & & Count & $\%$ & Count & $\%$ & Count & $\%$ \\
\hline \multirow{6}{*}{$\begin{array}{l}\text { Education level } \\
\text { of individual } \\
\text { respondent }\end{array}$} & Illustrate & 12 & 18.75 & 6 & 5.17 & 18 & 10 \\
\hline & Primary school (1-8) & 33 & 51.56 & 14 & 12.07 & 47 & 26.11 \\
\hline & Secondary/ preparatory school $(9-12)$ & 10 & 15.63 & 23 & 19.83 & 23 & 12.77 \\
\hline & $10 / 12+$ special training & 7 & 10.93 & 46 & 39.66 & 53 & 29.44 \\
\hline & College/university graduate & 2 & 3.13 & 27 & 23.28 & 29 & 16.11 \\
\hline & Total & 64 & 100 & 116 & 100 & 180 & 100 \\
\hline
\end{tabular}

Source: Own Survey, 2021 Family size of respondent

Family Size is the total number of family members who live under one roof (number of people living together and utilizing scarce resources together). As indicated in the data from respondents of this study also shows that returnee migrants family member categorized under $(<5)$ were about $(17.18 \%),(5-7)$ were about $(65.62 \%)$ and $(>7)$ were about $(17.18 \%)$, the most of migrant family size were categorized under (5-7). on the other hand non migrant family size show that $(56.03 \%)$ were $(<5),(37.93 \%)$ were $(5-7)$ and $6.03 \%$ were $(>7)$ and The mean of individuals their family size were participating on migration and these who are not participating 6.28 and 4.40 respectively and the overall mean of family size the sample individual respondents was found to be 5.05. Standard deviation of family size individual participating on migration and these who are not participating were 1.36 and 0.95 respectively and the mean difference of the family size were -1.87 and it is also significant at less than $1 \%$ level of significance. Based on the result this study, one can understand that the most exposed groups for migration their family size are large about $65.62 \%$ migrants family size categorized under (5-7) however most of non-migrants family size categorized under $(<5)$ about $56.03 \%$ (see table 5 below).

Table 5. Distribution of the individual respondent by their Family Size.

\begin{tabular}{llllllll}
\hline \multirow{2}{*}{ Variable } & \multirow{2}{*}{ Categories } & Migrants & \multicolumn{3}{c}{ Non migrants } & \multicolumn{3}{c}{ Total } \\
\cline { 3 - 8 } & & Count & \% & Count & \% & Count & \% \\
\hline Family size in & $<5$ & 11 & 17.18 & 65 & 56.03 & 76 & 42.22 \\
individual family & $5 \_7$ & 42 & 65.62 & 44 & 37.93 & 86 & 47.77 \\
& $>7$ & 11 & 17.18 & 7 & 6.03 & 18 & 10 \\
& Total & 64 & 100 & 116 & 100 & 180 & 100 \\
Mean & & 6.28 & & 4.40 & & 5.05 & \\
SD & & 1.36 & & 0.95 & & & \\
MD & -1.87 & & & & & \\
p-value & & 0.000 & & & & & \\
\hline
\end{tabular}

Source: Own Survey, 2021 Descriptive Analysis of the Economic Characteristics of the Respondents

Based on the occupation type of the respondents, About $(51.56 \%)$ of return migrants were engaged in unpaid family worker before they migrated followed by $(26.56 \%)$ casual laborer and $1.56 \%, 1.56 \%, 1.56 \%, 3.13 \%, 9.38 \%, 4.69 \%$ were represent trade, formal employ, farmer, student, unemployment and others respectively. on the other hand most of non-migrants during the time of survey were engaged in government employ about (37.07\%). The result indicated that occupation type is highly correlated with migration decision at time of the migrated. the occupation type for return migrants was different during the pre and post-migration. About (75\%) of return migrants were in engaged trade during the survey time and followed by student $(9.38 \%)$ and $15.63 \%$ others. Regarding monthly income of the return migrants, the result of the study reveals that about (51.56\%) of return migrant's income less than 500 ETB per month before they migrate because most of migrant's occupation were unpaid family worker. on the other hand most of non-migrants income during the time of survey were greater than 7000 ETB. about (22.41\%), $11.20 \%$ were (5000_7000) ETB and the remaining $66.37 \%$ were less than 5000 ETB. However, during post- migration, about $(50 \%)$ of return migrants have been earn more than 7,000 ETB per month due to now they open private business by their accumulated capital from abroad. the result indicated that low income is highly correlated with migration decision at time of the migrated, generally From this study, we can understand that low income and occupation type are the reasons for migration decision in the study area. Concerning their capital, the largest proportion, about (78.12\%) of return migrants had deposited less than 10,000 ETB during premigration. However, the largest proportion, about (45.31\%) of return migrants has accumulated $(50,000 \quad 100,000)$ ETB during post migration or the time of survey, on the other hand, about (57.75\%) of non-migrants have accumulated less than 100,000 ETB during the survey time of the researcher, Based on the result of the study, one can understand that the most exposed groups for migration their capital were low 
(see table 6 below).

Table 6. Descriptive Analysis of the Economic Characteristics of the Respondents.

\begin{tabular}{|c|c|c|c|c|c|c|c|}
\hline \multirow{2}{*}{ Variable } & \multirow{2}{*}{ Categories } & \multicolumn{2}{|c|}{ Migrants } & \multicolumn{2}{|c|}{ Non migrants } & \multicolumn{2}{|l|}{ Total } \\
\hline & & Count & $\%$ & Count & $\%$ & Count & $\%$ \\
\hline \multirow{9}{*}{$\begin{array}{l}\text { Occupation type } \\
\text { before migration }\end{array}$} & Trade & 1 & 1.56 & & & & \\
\hline & Farmer & 1 & 1.56 & & & & \\
\hline & Formal employ & 1 & 1.56 & & & & \\
\hline & Student & 2 & 3.13 & & & & \\
\hline & Casual labourer & 17 & 26.56 & & & & \\
\hline & Not working & 6 & 9.38 & & & & \\
\hline & Unpaid family worker & 33 & 51.56 & & & & \\
\hline & Other & 3 & 4.69 & & & & \\
\hline & Total & 64 & 100 & & & & \\
\hline \multirow{9}{*}{$\begin{array}{l}\text { Occupation type } \\
\text { during survey time }\end{array}$} & Trade & 48 & 75 & 15 & 12.93 & 63 & 35 \\
\hline & Farmer & 0 & 0 & 8 & 6.90 & 8 & 6.90 \\
\hline & Formal employ & 0 & 0 & 43 & 37.07 & 43 & 37.07 \\
\hline & Student & 6 & 9.38 & 16 & 13.79 & 22 & 12.22 \\
\hline & Casual labourer & 0 & 0 & 13 & 11.21 & & 11.21 \\
\hline & Unemployment & 0 & 0 & 5 & 4.31 & 5 & 4.31 \\
\hline & Unpaid family worker & 0 & 0 & 8 & 6.90 & 8 & 6.90 \\
\hline & Other & 10 & 15.63 & 8 & 6.90 & 18 & 10 \\
\hline & Total & 64 & 100 & 116 & 100 & 118 & 100 \\
\hline \multirow{3}{*}{$\begin{array}{l}\text { Income before } \\
\text { migration }\end{array}$} & Less than 500 ETB & 33 & 51.56 & & & & \\
\hline & 500 ЕТВ-2000 ЕТВ & 29 & 45.31 & & & & \\
\hline & 2000 and above & 2 & 3.12 & & & & \\
\hline \multirow{5}{*}{$\begin{array}{l}\text { Monthly income } \\
\text { during survey time }\end{array}$} & Total & 64 & 100 & & & & \\
\hline & $<5000$ ETB & 21 & 32.81 & 77 & 66.37 & 98 & 54.44 \\
\hline & 5000-7000 ЕТВ & 11 & 17.18 & 26 & 22.41 & 37 & 20.55 \\
\hline & $>7000$ ETB & 32 & 50 & 13 & 11.20 & 45 & 25 \\
\hline & Total & 64 & 100 & 116 & 100 & 180 & 100 \\
\hline \multirow{4}{*}{$\begin{array}{l}\text { Total capital before } \\
\text { migration }\end{array}$} & $<10,000$ ЕTВ & 50 & 78.12 & & & & \\
\hline & $10,000 \_30,000$ ЕТВ & 14 & 21.87 & & & & \\
\hline & $>30,000$ ETB & 0 & 0 & & & & \\
\hline & Total & 64 & 100 & & & & \\
\hline \multirow{4}{*}{$\begin{array}{l}\text { Total capital during } \\
\text { survey time }\end{array}$} & $<50,000$ ЕТВ & 27 & 42.18 & 67 & 57.75 & 94 & 52.22 \\
\hline & $50,000 \_100,0000$ ЕТВ & 29 & 45.31 & 34 & 29.31 & 63 & 35 \\
\hline & $>100,000$ ЕTB & 8 & 12.50 & 15 & 12.93 & 23 & 12.77 \\
\hline & Total & 64 & 100 & 116 & 100 & 180 & 100 \\
\hline
\end{tabular}

Source: Own Survey, 2021

Respondents or their family's size of land holding (in hectare)

Farm land Size is a basic asset of people's livelihoods in rural areas of the study. The number of population has been increasing and thus the average landholding and its productivity are decreasing from time to time in the study area. In addition to the decline of land productivity due to reduction of the fertility of the soil, other natural shocks such as drought, pest infestation, and scarcity of farmland are important factors of migration of rural people seeking for wage and related employment opportunities internally or internationally. About 53.12\% of returnee migrant's respondent's family have less 2 hectare farm lands at all and $46.87 \%$ have (2-4) hectare of land. On the other hand the data got from the non-migrant respondent show that the following are percent of family land size majority have below 2 hectare of land about 50\%, 31.03\% were (2-4) and the remaining $18.96 \%$ were greater than 4 hectare. This shows that most household have small plots of land (below 2 hectare) that have not been enough to feed the total household member or their family thus leading to migration in order to secure the household food security and The average cultivated land size of the sample of respondents was found to be 2.08 hectare with standard deviation of 0.79 and the average land holding of respondent family participants and the non-participants migration was 1.53 and 2.38 hectare respectively and mean difference 0.85 , it is also significance at less than $1 \%$ level of significance. (see below table 7).

Other push and pull factors of Migration in the study area: In spite of its complexity, the causes of migration decision are generally grouped into "push" or "pull" factors. The "pull" and "push" factors of migration can be economic or non-economic (i.e. demographic, social, natural and political). Push factors are associated with the conditions in 
the place of origin of migrants and seem to be more important in the developing world the reasons why people leave an area of residence for the economic and noneconomic reasons. Economic reasons might be lack of opportunities in home country like unemployment, low accesses of social services, increasing poverty etc, whereas non-economic reasons are, ethnic discrimination, political persecution at home, inter village conflict etc. pull factors are factors which attract condition people at the destination countries like job opportunities, political stability, better life and the more wealth, better services, and good climate, safe security reason, less crime, political stability, lower risk from natural hazards etc [13]. The "push -pull" factors of migration in the study area are discussed below.

Table 7. Descriptive Analysis Respondent's or their family's size of land holding (in hectare).

\begin{tabular}{|c|c|c|c|c|c|c|c|}
\hline \multirow{2}{*}{ Variable } & \multirow{2}{*}{ Categories } & \multicolumn{2}{|c|}{ Migrants } & \multicolumn{2}{|c|}{ Non migrants } & \multicolumn{2}{|l|}{ Total } \\
\hline & & Count & $\%$ & Count & $\%$ & Count & $\%$ \\
\hline \multirow{4}{*}{$\begin{array}{l}\text { Respondents or their } \\
\text { family's size of land } \\
\text { holding (in hectare) }\end{array}$} & $<2$ & 34 & 53.12 & 58 & 50 & 92 & 51.11 \\
\hline & $2-4$ & 30 & 46.87 & 36 & 31,03 & 66 & 36.66 \\
\hline & $>4$ & 0 & 0 & 22 & 18.96 & 22 & 12,22 \\
\hline & Total & 64 & 100 & 116 & 100 & 180 & 100 \\
\hline Mean & & 1.53 & & 2.38 & & 2.08 & \\
\hline $\mathrm{SD}$ & & 0.68 & & 0.67 & & 0.79 & \\
\hline MD & & 0.85 & & & & & \\
\hline p-value & & 0.000 & & & & & \\
\hline
\end{tabular}

Source: Own Survey, 2021.

Push factors of migration: The result of the study revealed that many push factors have contributed for the migration decision in the zones, From Cause of migration of push factors for young adult migration (from table 8), migrants wants open up or extend personal business has contributed the highest proportion, about $28.96 \%$ followed by unemployment $28.42 \%$, natural disaster (like drought, famine) $8.20 \%$, experience of crop failure $7.65 \%$, disagreement with family $6.01 \%$, family shock factors like death, divorce of family member $4.37 \%$, agricultural land shortage $3.83 \%$, family pressure $3.28 \%$, lack of social services (health, electricity, transportation etc) $3.28 \%$, political problem $3.28 \%$, to free from cultural or family restrictions and obligation $2.73 \%$. On the other hand the data got from the non-migrant respondent show that the following are percents of pushing factor contribution for migration $26.48 \%$ unemployment, $21.92 \%$ to open personal business,
$13.24 \%$ low access of credit, $7.31 \%$ natural disaster (like drought, famine), $6.39 \%$ experience crop failure, $5.02 \%$ disagreement with family, $3.20 \%$ land shortage, 3.20 political problem, $3.20 \%$ family shock factors like death, divorce of family member, $2.74 \%$ to free from cultural or family restrictions and obligation, $2.74 \%$ family pressure, and 2.28 others from highest to lowest. As mentioned above, among the push factors of migration, unemployment followed by the person intended to open private business has contributed the highest percentage for the migration in the study area. This is related to lack of various job opportunities due to lack of the good governance or lack of commitment of the local government officials to create job opportunities for the young and adult people has been making them to be hopeless and lack of vision for future life and then choose migration as an optimal option to improve their livelihoods.

Table 8. Descriptive statistics for push factors of migration in study area.

\begin{tabular}{|c|c|c|c|c|c|c|c|}
\hline \multirow{2}{*}{ Variable } & \multirow{2}{*}{ Categories } & \multicolumn{2}{|c|}{ Migrants } & \multicolumn{2}{|c|}{ Non migrants } & \multicolumn{2}{|l|}{ Total } \\
\hline & & Count & $\%$ & Count & $\%$ & Count & $\%$ \\
\hline \multirow{14}{*}{$\begin{array}{l}\text { Push } \\
\text { factors of } \\
\text { migration }\end{array}$} & To free from cultural or family restrictions and obligations & 5 & 2.73 & 6 & 2.74 & 11 & 2.73 \\
\hline & family shock factors like death, divorce etc & 8 & 4.37 & 7 & 3.20 & 15 & 3.73 \\
\hline & To open up or extend personal business & 53 & 28.96 & 48 & 21.92 & 101 & 25.12 \\
\hline & Natural disaster (like drought, famine) & 15 & 8.20 & 16 & 7.31 & 31 & 7.71 \\
\hline & Disagreement with family & 11 & 6.01 & 11 & 5.02 & 22 & 5.47 \\
\hline & Unemployment & 52 & 28.42 & 58 & 26.48 & 110 & 27.36 \\
\hline & Political problem & 6 & 3.28 & 7 & 3.20 & 13 & 3.23 \\
\hline & Land shortage & 7 & 3.83 & 7 & 3.20 & 14 & 3.48 \\
\hline & Family pres pressure & 6 & 3.28 & 6 & 2.74 & 12 & 2.98 \\
\hline & experience of crop failure & 14 & 7.65 & 14 & 6.39 & 28 & 6.96 \\
\hline & Lack of social services (health, electricity, transportation). & 6 & 3.28 & 5 & 2.28 & 11 & 2.73 \\
\hline & Low access of credit & & & 29 & 13.24 & 29 & 7.21 \\
\hline & Other & & & 5 & 2.28 & 5 & 1.23 \\
\hline & Total & 183 & 100 & 219 & 100 & 402 & 100 \\
\hline
\end{tabular}

Source: Own Survey, 2021. 
migration decision in the zones, however the major pull factors for migration decision of adult in the study area were (from table 9) job opportunities, high income, social networks, peer pressure at destination, lure of attractive climatic condition, to join relatives, further study (education) and training and smugglers were identified as the main pull factors that have been attracting youths and adults to out the country. The result of the study reveals that, $21.60 \%$ job opportunities, $18.89 \%$ high income at destination, $18.09 \%$ social networks, $8.79 \%$ peer pressure at destination, $6.53 \%$ lure of attractive climatic condition, $4.52 \%$ to join relatives, $4.77 \%$ further study (education) and training, $13.31 \%$ smugglers were and 3.53 others. The researcher used average percentage of migrants and non-migrant because the result of the study migrants and non-migrants show that almost the same. Job opportunities, better income, social networks and smuggler contributed the highest proportion for migration decision in the study area.

Table 9. Descriptive statistics for pull factors of migration in study area.

\begin{tabular}{|c|c|c|c|c|c|c|c|}
\hline \multirow{2}{*}{ Variable } & \multirow{2}{*}{ Categories } & \multicolumn{2}{|c|}{ Migrants } & \multicolumn{2}{|c|}{ Non migrants } & \multicolumn{2}{|l|}{ Total } \\
\hline & & Count & $\%$ & Count & $\%$ & Count & $\%$ \\
\hline \multirow{10}{*}{$\begin{array}{l}\text { Pull } \\
\text { factors of } \\
\text { migration }\end{array}$} & high income at destination & 32 & 19.51 & 43 & 18.38 & 75 & 18.84 \\
\hline & Employment opportunity at destination & 45 & 27.44 & 41 & 17.52 & 86 & 21.60 \\
\hline & peer pressure at destination & 11 & 6.71 & 24 & 10.26 & 35 & 8.79 \\
\hline & Lure attractive climatic condition at destination & 11 & 6.71 & 15 & 6.41 & 26 & 6.53 \\
\hline & Social media & 23 & 14.02 & 49 & 20.94 & 72 & 18.09 \\
\hline & Smuggler & 17 & 10.37 & 36 & 15.38 & 53 & 13.31 \\
\hline & To join immediate relatives & 7 & 4.27 & 11 & 4.70 & 18 & 4.52 \\
\hline & further study (education) & 9 & 5.49 & 10 & 4.27 & 19 & 4.77 \\
\hline & Others & 9 & 5.49 & 5 & 2.14 & 14 & 3.51 \\
\hline & Total & 164 & 100 & 234 & 100 & 398 & 100 \\
\hline
\end{tabular}

Source: Own Survey, 2021.

Way of migration in the study area: Evidences show that almost all of Ethiopians; migrants have been travelling illegal way. Illegal migration has become a growing international challenge which needs a great attention. Illegal migration by definition is migration that occurs without the proper documentation, measuring the extent of it is difficult. But The result of this study a showed that the mentioned figure (see figure 1 below) the majorities of $75 \%$ migrants have been moving in illegal way. However, a few $25 \%$ have been travelling in legal way in the study area. The result of the study showed that most people migrate through illegal way in the zone.

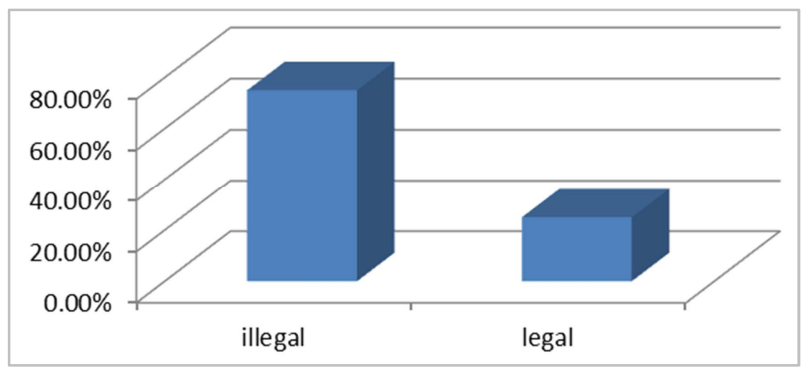

Source: Own Survey, 2021

Figure 1. Descriptive statistics legality of migration in the study area.

Econometric Analysis:

Factors influencing migration decision: the case of eastern zone: Under this section the binary logistic regression model was employed to identify the determinant factors that could affect migration decision and to analyze the relationship between the dependent variable and the independent variables; namely gender, age, family size, level of education, income earned in abroad, family or individual respondents land size and family shocks in the study area. The model predicts the log odds of the dependent variable. $P i /(1-P i)$ is the ratio of a probability that individual is involved in migration to probability that individual is not involved migration. Taking the natural logarithms of the odds ratio, the logistic regression model migration is a function of several determinant factors given as follows:

$$
\begin{gathered}
\mathrm{y}=\ln \left(\frac{\mathrm{pi}}{1-\mathrm{pi}}\right)=\beta 0+\beta 1 \text { gendar }+\beta 2 \text { age }+\beta \text { Fsize }+\beta 4 \text { eduLevel }+\beta 5 \text { Iabr } \\
\text { oad }+\beta 6 \text { FLSize }+\beta 7 \text { Fshocks }+e .
\end{gathered}
$$

The regression coefficient together with their sign indicates the magnitude and direction of the effect in the log odds, being the category of interest of response variable for a unit of increase in the predictor variable. However after undergoing the analysis, multicollinearity, goodness of fit of the model and model specification diagnoses test are checked to avoid variables that may affect the model output. In Logistic regression model does not assume a linear relationship between the dependent and independent variables, the dependent variables do not need to be normally distributed, there is no homogeneity of variance assumption, in other words the variances do not have to be the same within categories, normally distributed error terms are not assumed and the independent variables do not have to be interval or unbounded [7].

Multicollinearity effects

Multicollinearity is a phenomenon in which two or more independent variables in logistic regression model are highly correlated, meaning that one can be linearly predicted from the others with a substantial degree of accuracy. Therefore, 
VIF were used for the continuous variable and pair wise test was used for the discrete variables, to check multicollinearity. VIF shows how the variance of an estimator is inflated by the presence of multicollinearity. As R2 approaches 1, the VIF increased tremendously. That is, as the extent of collinearity between the variables increases, the variance of an estimator increases, and in the limit it can become infinite [10]. The value of VIF greater than 10 was an indicator of a serious multicollinearity problem and it used to omit such variables from the model. However, in this analysis the values of VIF were less than 10 (see below table 10). Hence, there was no as such problem of multicollinearity among continuous independent variable. Then all the four continuous explanatory variables were used into logistic analysis. $\mathrm{VIF}=\frac{1}{1-\mathrm{R}^{2}}$

Table 10. Colinearity Diagnosis for Continuous Explanatory Variables.

\begin{tabular}{lll}
\hline Variable & VIF & 1/VIF \\
\hline Age & 10.08 & 0.092559 \\
FLsize & 8.39 & 0.119130 \\
Fsize & 6.02 & 0.166021 \\
Income & 1.81 & 0.553350 \\
Mean VIF & 6.76 & \\
\hline
\end{tabular}

Source: Computed from own survey, 2021

On the other hand the discrete variables were undergoing in to the muticollinearity test through pair-wise correlation test. As shown in the Table below, there is no as such significant association among the variables.

So far the multicollinearity tests for both continuous and discrete variables assured that there is no as such problematic multicollinearity that could affect the model. As a result all the seven explanatory variables were direct into logistic analysis to identify the determinants factors of migration.

Assessing Goodness of Fit of the Model

Table 11. Coolinearity Diagnosis for Discrete Explanatory Variables.

\begin{tabular}{llll}
\hline Variable & Gender & Fshoch & edulevel \\
\hline Gender & 1.0000 & 1.0000 & \\
Fshock & -0.1339 & 0.0811 & 1.0000 \\
Edulevel & 0.1223 & & \\
\hline
\end{tabular}

Source: Computed from Own survey, 2021

One of the techniques used to assess the goodness of fit tests overall fit of a logistic regression it is also called the chi-square test which measures the correspondence between the actual and predicted values of the dependent variable [11]. The Hosmer and Lemeshow goodness of fit test divides cases into deciles based on predicted probabilities (Table 12) and then computes chi-square value from observed and expected frequencies presented in (Table 13). The stata output shows the non-significance of the chisquare value. Hence, we do not reject the null hypothesis that is no difference between the observed and expected frequencies which indicates that the model adequately fits the data. We conclude that the model adequately fits the data.
Table 12. Results of Hosmer and Lemeshow Test.

\begin{tabular}{llll}
\hline & Chi square & Df & Sig \\
\hline Final step & 5.90 & 8 & 0.6581 \\
\hline
\end{tabular}

Table 13. Results of Contingency Table for Hosmer and Lemeshow Test.

\begin{tabular}{lllllll}
\hline \multirow{2}{*}{ Group } & \multirow{2}{*}{ Pro } & \multicolumn{2}{l}{ Returnee migrant } & \multicolumn{2}{l}{ Non migrant } & \multirow{2}{*}{ Total } \\
\cline { 3 - 6 } & & Obs & Exp & Obs & Exp & \\
\hline 1 & 0.0000 & 0 & 0.0 & 18 & 18.0 & 18 \\
2 & 0.0000 & 0 & 0.0 & 18 & 18.0 & 18 \\
3 & 0.0000 & 0 & 0.0 & 18 & 18.0 & 18 \\
4 & 0.0000 & 0 & 0.0 & 18 & 18.0 & 18 \\
5 & 0.0007 & 0 & 0.0 & 18 & 18.0 & 18 \\
6 & 0.2064 & 0 & 0.6 & 18 & 17.4 & 18 \\
7 & 0.8290 & 12 & 0.9 & 6 & 8.1 & 18 \\
8 & 0.9997 & 16 & 17.5 & 2 & 0.5 & 18 \\
9 & 1.0000 & 18 & 18.0 & 0 & 0 & 18 \\
10 & 1.0000 & 18 & 18.0 & 0 & 0 & 18 \\
\hline
\end{tabular}

Source: Computed from Own survey, 2021

Through the classification table, the correct predications of all the samples used were $97.22 \%$, whereas the sensitivity (correct prediction of returnee migrants adult) is $96.88 \%$ and Specificity (correct prediction of non-migrants adult) is $97.41 \%$.

In the last the Nagelkerke pseudo R-square was used to know how well the variables used in the model explains in the variation of data. In this regard, the variables employed in this study were in a position to explain $87 \%$ of the variations. In the other word there are also other variables that could influence households' international migration decision.

After observing how the model fits well, it is now time to see how each of the explanatory variables affects the adult migration decision in the study area. Binary logistic regression in this study is based on the dependent variable (migration decision) is coded as 1 if the respondent is migrant and a value of 0 if the respondent is non-migrant. As shown in the below table 14 out of the seven explanatory variables, five of them significantly influence on adult migration decision. These are age, family size (FSize), family land size (Fland), income and family shock (Fshock).

As hypothesized, the total number of family member (Fsize) influence migration decision positively and significantly at less than $1 \%$ significance level $(\mathrm{p}<0.01)$, maintaining other determinants constant. Since labor is the main input in crop production, larger households face fewer labor bottlenecks at critical points in the farming cycle such as land preparation and Harvest time. Thus, family size is hypothesized to determine migration positively in one or other ways. Results show that there is positive association between migration of family members and size of family as the size of family increased the per capita income of the household decreased and the faced the problems of livelihood. Therefore, the family members had to migrate in search of a job. The odd ratio value in Table 14 indicated that, with one unit increase in family size, the probability of migration of family members increased by a factor of 3.124645. The model output for this variable also conform to the initial expectation of this study, in which as the family 
size becomes the push factor for individual to undertake migration in the study area.

Table 14. Logistic Regression Model Output for the Entire Explanatory Variables.

\begin{tabular}{lllll}
\hline Variable & Coefficient & Odds Ratio & $\mathbf{Z}$ & Level sign \\
\hline Gender & -1.196292 & .3023132 & -0.90 & 0.370 \\
Age & -.5196303 & .5947404 & $-2.88^{* *}$ & 0.004 \\
Fsize & 3.124645 & 22.75181 & $2.72^{* *}$ & 0.007 \\
FLsize & -4.087987 & .016773 & $-2.18^{*}$ & 0.029 \\
Iabroad & .000796 & 1.000796 & $2.57^{* *}$ & 0.010 \\
Fshock & 9.036235 & 8402.083 & $2.82^{* *}$ & 0.005 \\
Edulevel $\quad 1.859345$ & 6.419528 & 1.56 & 0.119 \\
Dependent variable migration decision & & \\
Number of obs $=180$ & & & \\
LR chi2(7) $=204.72$ & & & \\
Prob $>$ chi2 $=0.0000$ & & & \\
Pseudo R2 $=0.8738$ & & & \\
Log likelihood $=-14.7$ & & & \\
\hline
\end{tabular}

Source: Computed From Own Survey, $2021 * *$ And * represents the significance level at $1 \%$, and $5 \%$ respectively.

The size of land cultivated, as a basic input in farming, is significantly associated with food security status of a family member. Land in this zone serves as means of coping mechanism during serious food shortage and collateral to receive credit service. This means households with large cultivated land produce more for household consumption and sale and have better chance to be food secure than those having relatively small size of cultivated land. The results in Table 14 indicated that a the total number of family land size (Fland) influence migration decision negatively and significantly at less than $5 \%$ significance level $(p<0.05)$, maintaining other determinants constant, the odds ratio for this variable indicates that, additional unit of cultivated land will reduce the probability of out-migration by factor of 0.016773 . The result indicating that households with large cultivated land are less likely to be food insecure and vice versa which is the same to migration of the household to move elsewhere to fill the gap of food insecurity for themselves or their families.

As expected of the family shock (Fshock) found to influence individuals' migration decision positively and significantly at less than $1 \%$ probability level $(p<0.01)$. The odds ratio favoring migration decision increase by the factor of 8402.083 for individuals with family shocks in their family for example death, divorce. The result have showed agreement with the anticipated hypothesis in which individual with family shock in their family are exposed for migration due to they become helpless to attained education.

The income earned from abroad as compared to the zone is the major motivator in adult migration decision. The results in Table 14 indicated that a the income earned from abroad (income) influence migration decision positively and significantly at less than $1 \%$ significance level $(\mathrm{p}<0.01)$, maintaining other determinants constant, the odds ratio for this variable indicates that, additional unit of income from abroad will increase the probability of out-migration by factor of 1.000796 .
Age of the individuals (age): is found to be a significant and negatively influence on adult migration decision in eastern zone of Tgray state at less than $1 \%$ significance level $(p<0.01)$, The negative sign of the coefficient of age indicates that odds ratio in favor of the probability of migration decision decreases as age increases i.e. all other things are held constant, the odds ratio in favor of migration decision decrease by a factor of 0.5947404 as age increase by one year. This implication indicates that, as the age of the individual increases their economically active age group are pass and their migration decision are decrease.

Whereas gender and individual education level are expected to influence the migration decision of adults, these variables have had no significant effect on adult migration decision in case of the current finding, though the relationship was not significant, the likelihood of migration decision for adult is 0.3023132 and 6.419528 respectively. This indicates that gender can't force migration decision rather than gender migration is affected by age group (economically active age). In similar fashion level of education is nothing to do with migration rather migration is encouraged by expected income from abroad by comparing their low income in the study area.

\section{Conclusions and Policy Implication}

This study found that some of the demographic and socioeconomic variables have been a significant influence on young adult migration from eastern zone of Tigrai. The investigation was done mainly on the quantitative and qualitative data collected via 180 questionnaire from randomly selected 64 returnees migrants and 116 nonmigrants between April and May 2019. Binary logit model was employed in addition to descriptive statistics to investigate socio economic and demographic factors that affected migration decision in the study area. Analysis the respondents' demographic and socio-economic characteristics as well as their responses on pull-push factors of migration, effect of migration and patterns of migration, an attempt has been done Regarding gender as one of the demographic factors of migration, the result of the study indicates that the majority of them were female, about $(59.38 \%)$ of return migrants. Concerning the education status, the migration rate was found significantly higher for those who were at the primary school level of educational attainment. About (51.56\%) of return migrants were categorized in the primary education level. Concerning the family size, the migration rate was found significantly higher for those who were in large family size. About (65.62\%) of return migrants were categorized in their family size were between (5-7). Regarding the economic characteristics of the respondents, in the type of occupation, the majorities, about $(51.56 \%)$ of return migrants were engaged in unpaid family work followed by casual laborer when they migrate from zone. This shows that occupation type has direct correlation with the migration decision in the study area. However, this figure increased during the post-migration, about (75\%) of 
return migrants are engaged in trade. Concerning per month income, before migration, about $(51.56 \%)$ of return migrants were earn less than 500 ETB per month due to most individual were work in unpaid family work whereas the largest proportion, about $(50 \%)$ of return migrants have been earned greater than 7000 ETB per month during post migration. Regarding their capital, the largest percentage, about $(78.12 \%)$ of return migrants were accumulated less than 10,000 ETB before migration whereas, about (45.31\%) of return migrants have accumulated (50,000-100,000 ETB) during post migration (survey time of the researcher). Concerning the family or respondent farm land size, the migration rate was found significantly higher for those who were in their family land size small. About (53.12\%) of return migrants were categorized their family land size were less than 2 hectares. On the other hand, as discussed in detail in the literature, the causes of migration from the study area have been fuelled by a variety of "Push-pull" factors. Concerning the ways of migration from eastern zone, the finding of the study shows that over $75 \%$ have been moving in illegal way with serious health and life risky conditions. in binary logit analysis the main determinant forces or variables significantly affect migration decision were age, family size, family shocks, family or individual respondent land size and high income at destination.

\section{Recommendation}

After analyzing the socio economic factors that has high contribution to migration from eastern zone. The researcher forwarded the following suggestions: the concerned bodies at different level should give emphasis to the multiple factors of migration. the total number of family or individual land size influence migration decision significantly and negatively then to solve the problem of land shortage government should encourage small scale industries and create various job opportunities for youth and adults because youth are most migratory group; the government has to consider building vocational training institution; Vocational training of the people on small scale industries (non-farm) activities that could generate income for the households should be introduced as it is supposed to alleviate the problems of landlessness and shortage of agricultural land and their total dependency on one source of livelihood i.e. traditional farming, Train rural youth families about the successful soil and water conservation practices as well the appropriate agronomic practices to reduce rural poverty, establishment of sufficient primary and secondary school with minimum standard could reduce the migration trend of adults, favorable conditions should be created to an enabling environment for adults entrepreneurship and creativity so that they can get alternative livelihood option in the residence without migration, Provide and facilitating access to credit availability and capital through microfinance institution, family size are influence migration decision positively and significantly then government should prove family planning services and with the help of the development policy and strategies put in place by the GO and
NGOs, the community and other development stoke-holders working in the area would have to design interventions contributing to reducing unemployment which are the main causes of migration. There should be also Extensive and continues information campaigns have to be done in order to promote public awareness concerning the threats of smuggling, sufferings of the migrants, deportation from the transit countries and human rights violations via print and electronic media like radio, television, Twitter, face book and YouTube videos. The government officials at different levels have to take strong actions on smugglers Finally family and as whole of society should be advice, and facilitate and encourage their children to work in their residence rather than to decide migration and solving the socio economic problems of the family.

\section{References}

[1] Abrha, F. (2017). Determinants of youth migration the case of tsegedie wereda Tigray regoinal state. Aksum university, Ethiopia.

[2] Adamnesh, A. (2006), "Aspects of Ethiopian Return Migration." Institute of Regional and Local Development Studies. Addis Ababa University, Ethiopia.

[3] Adepoju, A. (1995). Emigration Dynamics in Sub-Saharan Africa: International migration. Special Issue: Emigration Dynamics in Developing countries, vol. 33, no, 314.

[4] Belayneh G and G. Y Sagar. (2016) The Determinant Factors Of Illegal Migration To South Africa And Its Impacts On The Society In Case Of Gombora District, Hadiya Zone In Ethiopia Hawassa University, Hawassa, Ethiopia.

[5] Bisrat, W. (2014). International Migration and Its Effects on Socio-Economic Wellbeing of Migrant Sending Households. MA Thesis Submitted Department of Management, Program of Development Studies, Mekelle University.

[6] CSA (1999). Population and Housing Census Report: Central Statistics Authority, Addis abeba, Ethiopia.

[7] Girmy tadele. (2015). a critical assessment of the violations of rights of girls during irregular migration: the case of woreda sa'esi'e tsa'edamba in eastern zone of tigray addis abeba university, Ethiopia.

[8] Gujarati, Damodar N. (2004). Basic Econometrics: Fourth Edition, the McGraw- Hill Companies, Inc., New York.

[9] Hosmer and Lemeshow (1998). Applied Logistic Regression, 2nd Ed., University of Massachusetts and the Ohio State University, Massachusetts and Columbus.

[10] Kerlinger, B. (2019). The migration experiences in Africa Stockholm. Nordiska Africa institute.

[11] Massey et al. (1993), Theories of international migration: a review and appraisal," Population and Development Review 19 (3): 431-466.

[12] National Geographic Society. (2019). Human Migration Guide. Available from: http://www.nationalgeographic.com/xpeditionslessons/09/g68/ migrationguidestudentpdf. 
Tigrai Regional State, Ethiopia

[13] Solimana, Andrés (2001). International Migration and the Global Economic Order: An overview. Macroeconomics and Growth Development Economics Research Group, published by World Bank.

[14] Wright, R. E. (1995). "Logistic regression". In L. G. Grimm \& P. R. Yarnold, eds., Reading and understanding multivariate statistics. Washington, DC: American Psychological Association. A widely used recent treatment.
[15] Zelalem, T. (2011). The Challenges of Child Labor Migration, Voluntary Repatriation, Family Tracing and Reunification, Addis Ababa. 